Roger Williams University

DOCS@RWU

\title{
Hormone and Metabolite Changes associated with Extended Breeding Fasts in Male Northern Elephant Seals (Mirounga Angustirostris)
}

\author{
Daniel E. Crocker \\ Sonoma State University \\ Rudy M. Ortiz \\ University of California \\ Dorian S. Houser \\ National Marine Mammal Foundation \\ Paul M. Webb \\ Roger Williams University, pwebb@rwu.edu \\ Daniel P. Costa \\ University of California, Santa Cruz
}

Follow this and additional works at: https://docs.rwu.edu/fcas_fp

Part of the Biology Commons

\section{Recommended Citation}

Crocker, D. E., R. M. Ortiz, D.S. Houser, P.M. Webb and D. P. Costa. 2012. "Hormone and metabolite changes associated with extended breeding fasts in male northern elephant seals (Mirounga angustirostris)." Comparative Biochemistry and Physiology A 161(4):388-394.

This Article is brought to you for free and open access by the Arts and Sciences at DOCS@RWU. It has been accepted for inclusion in Arts \& Sciences Faculty Publications by an authorized administrator of DOCS@RWU. For more information, please contact mwu@rwu.edu. 


\title{
Hormone and metabolite changes associated with extended breeding fasts in male northern elephant seals (Mirounga angustirostris)
}

\author{
Daniel E. Crocker ${ }^{\text {a,* }}$, Rudy M. Ortiz ${ }^{\text {b }}$, Dorian S. Houser ${ }^{c}$, Paul M. Webb ${ }^{\text {d }}$, Daniel P. Costa ${ }^{\text {e }}$ \\ a Department of Biology, Sonoma State University, Rohnert Park, CA 94928, USA \\ b School of Natural Sciences, University of California, Merced, CA 95343, USA \\ c National Marine Mammal Foundation, San Diego, CA 92106, USA \\ d Department of Biology, Roger Williams University, Bristol, RI 02809, USA \\ e Department of Biology, University of California, Santa Cruz, CA 95064, USA
}

\section{A R T I C L E I N F O}

\section{Article history}

Received 25 October 2011

Received in revised form 16 December 2011

Accepted 20 December 2011

Available online 29 December 2011

\section{Keywords:}

Elephant seal

Thyroxine

Deiondination

DDE

Fasting

Leptin

Ghrelin

Cortisol

Adipose tissue

\begin{abstract}
A B S T R A C T
We measured metabolic hormones and several key metabolites in breeding adult male northern elephant seals to examine the regulation of fuel metabolism during extended natural fasts of over 3 months associated with high levels of energy expenditure. Males were sampled twice, early and late in the fast, losing an average of $23 \%$ of body mass and $47 \%$ of adipose stores between measurements. Males exhibited metabolic homeostasis over the breeding fast with no changes in glucose, non-esterified fatty acids, or blood urea nitrogen. Ketoacids increased over the fast but were very low when compared to other fasting species. Changes within individuals in total triiodothyronine $\left(\mathrm{tT}_{3}\right)$ were positively related to daily energy expenditure (DEE) and protein catabolism. Differences in levels of thyroid hormones relative to that observed in weaned pups and females suggest a greater deiodination of $\mathrm{T}_{4}$ to support the high DEE of breeding males. Relative levels of leptin and ghrelin were consistent with the suppression of appetite but a significant reduction in growth hormone across the fast was contrary to expectation in fasting mammals. The lack of the increase in cortisol during fasting found in conspecific weaned pups and lactating females may contribute to the ability of breeding males to spare protein despite high levels of energy expenditure. Together these findings reveal significant differences with conspecifics under varying nutrient demands, suggesting metabolic adaptation to extended high energy fasts.
\end{abstract}

(c) 2011 Elsevier Inc. All rights reserved.

\section{Introduction}

Long-term fasts are an important component of the life-history of numerous species (Castellini and Rea, 1992; Cherel and LeMaho, 1985). Extended fasting is characterized by mobilization and use of lipid for energy metabolism and reduced mobilization and use of body proteins stores for gluconeogenesis and metabolism (e.g. Cherel et al., 1992). For many species extended fasts are associated with periods of reduced body temperature and activity levels (e.g. Cherel et al., 1995) and it has been suggested that reductions in the metabolic rate are a key factor in facilitating effective protein sparing during extended fasts (Henry et al., 1988). Terrestrial parturition and marine feeding have led to extended fasts during breeding in numerous species of pinnipeds. However, male pinnipeds often maintain high rates of energy expenditure while fasting in the process of maintaining territory or controlling access to females (Crocker et al., 2012). The ability to minimize protein loss over extended fasts may positively impact sustainable levels of energy expenditure and tenure

\footnotetext{
* Corresponding author at: Department of Biology, Sonoma State University, $1801 \mathrm{E}$. Cotati Ave., Rohnert Park, CA 94928, USA. Tel.: + 1707664 2994; fax: + 17076644046. E-mail address: crocker@sonoma.edu (D.E. Crocker).
}

in breeding adult males, both of which are directly associated with reproductive success (Anderson and Fedak, 1985; Deutsch et al., 1990; Lidgard et al. 2005). However, the regulation of metabolism during these high-energy fasts is poorly understood.

Elephant seals have the highest sustained rates of fasting energy expenditure found in male pinnipeds (Crocker et al., 2012). Males compete for position in a dominance hierarchy used to control access to estrus females (Le Boeuf, 1974; Haley et al., 1994) while fasting from food and water, losing $\sim 36 \%$ of their arrival body mass over a 3-month period (Deutsch et al., 1994; Crocker et al., 2012). During this period, males have low rates of water flux and spare protein efficiently (Ortiz et al., 2006; Crocker et al., 2012). Studies in fasting and lactating female elephant seals have suggested reduced insulin response and sensitivity (Fowler et al., 2008; Viscarra et al., 2011a, 2011b). To date, no studies have examined the hormone regulation of metabolism in adult male pinnipeds during natural breeding fasts. This is of particular interest because these breeding fasts are associated with high sustained energy expenditures, which is not common amongst mammals.

Previous studies on fasting animals have suggested the importance of low levels of glucocorticoids, insulin and thyroid hormones in maintaining efficient protein sparing during phase II fasting and that 
increases in protein catabolism are associated with increases in levels of glucocorticoids and glucagon as fasting progresses (e.g. Cherel et al., 1992). Low insulin-to-glucagon ratios are thought to be the important regulators of increased lipolytic, ketogenic and gluconeogenic process during extended fasting (Cahill, 1978). Insulin promotes synthesis of lipids and proteins while inhibiting the activity or expression of enzymes that catalyze degradation. However the regulation of insulin signaling pathways is complex with numerous other hormones and signaling events attenuating insulin action (Saltiel and Kahn, 2001).

The metabolic effects of growth hormone $(\mathrm{GH})$ during fasting are complex and involve increased lipolysis, protein retention and impaired suppression of hepatic glucose production (Norrelund, 2005). The contribution of hormonal regulation to protein sparing during extended fasting and the degree to which potential secondary mediators contribute to the metabolic action of GH during fasting has not been completely investigated (Cahill, 1979: Cherel et al., 1992; Norrelund 2005). Under non-fasting conditions, GH stimulates hepatic release of insulin-like growth factor (IGF-1) which supports protein anabolism. Paradoxically, fasting is associated with both elevation in GH and suppression of IGF-1, possibly due to reduced hepatic GH receptors (Straus and Takemoto, 1990). This inhibition of IGF-1 secretion is thought to remove negative feedback on GH releasing hormone, allowing hypersecretion of GH during fasting (Straus and Takemoto, 1990).

Several studies have suggested that the hormone leptin may be a key regulator of the systemic metabolic response to fasting (Ahima et al., 1996). Leptin increases lipid oxidation and reduces triacylglycerol synthesis. In mammals, the progression of food deprivation generally results in a decrease in leptin within a few days of the cessation of food consumption (Kolaczynski et al., 1996; Mustonen et al., 2005). This in turn suppresses the thyroid axis to conserve energy (Boelen et al., 2008) and dis-inhibits the production of neuropeptide Y (NPY) resulting in the stimulation of feeding (Williams et al., 2004). Ghrelin antagonizes the action of leptin and stimulates the production of NPY (Shintani et al., 2001). The role of these hormones in naturally fasting animals that undergo appetite suppression and large changes in adipose composition are not well understood.

We measured several key metabolites over the breeding fast in adult male northern elephant seals (Mirounga angustirostris) to examine the changes in fuel metabolism during extended fasts associated with high levels of energy expenditure. We examined changes in several important metabolic hormones over the breeding fast, including insulin, glucagon, cortisol, total triiodothyronine $\left(\mathrm{tT}_{3}\right)$, total thyroxine $\left(\mathrm{tT}_{4}\right), \mathrm{GH}$, insulin growth factor 1 (IGF-1), leptin and ghrelin. The potential physiological roles of many of these hormones are poorly understood in mammals adapted to prolonged fasting. In addition, we examined several key metabolites, including glucose, nonesterified fatty acids (NEFA), blood urea nitrogen (BUN) and betahydroxy butyrate $(\beta-H B A)$. Our aim was to look for changes in hormone or metabolite concentrations over the duration of the fast and to relate these changes to differences in energy expenditure and protein catabolism over the same period in breeding males. Sex and life history variation with conspecifics and comparison to other fastingadapted species will help identify features that potentially represent adaptations to extended fasts under conditions of high rates of metabolism.

\section{Methods}

All methods were reviewed and approved by University of California Santa Cruz Chancellor's Animal Research Committee.

\subsection{Study site and study animals}

Research was conducted under National Marine Fisheries Service marine mammal permit No. 836. All procedures were approved by the UCSC Chancellor's Animal Research Committee. Nineteen adult male seals from Año Nuevo State Reserve, CA were studied during the 1998 breeding season. Animals were considered adult based on body mass and development of secondary sexual characteristics (Le Boeuf, 1974; Deutsch et al., 1990). Individuals were identified by pre-existing flipper tags and dye marks (Lady Clairol, Stamford, CT, USA). Males were marked immediately upon being sighted at the study site, but it is possible that they hauled out at other areas of the rookery not under observation prior to being sighted.

\subsection{Field procedures}

Males were sampled twice during the breeding season; in January (Early Fast) and again in late February or early March (Late Fast). Adult males were lured onto a platform truck scale (Senstek, Inc. Saskatoon, SK, Canada; $\pm 5 \mathrm{~kg}$ ) by using a plaster model of an adult female elephant seal (Deutsch et al., 1994). Body composition at each sample was obtained from isotopic dilution of $185-296 \mathrm{MBq}{ }^{3} \mathrm{H}_{2} \mathrm{O}$. See Crocker et al. (2012) for detailed field methods for body composition determination. All samples analyzed for hormones or metabolites were collected within 30 min of initial immobilization.

\subsection{Body composition and energy expenditure}

Total body water (TBW) and body composition were estimated using isotopic dilution (ID) of tritium. The activity of ${ }^{3} \mathrm{H}$ in the water of each plasma sample was measured in triplicate, $100 \mu \mathrm{L}$ aliquots of plasma, using the freeze-capture method (Ortiz et al., 1978). Samples were counted in $10 \mathrm{~mL}$ of Ecolite scintillation cocktail using a Beckmann LS3801 scintillation counter. The activity of an injectate standard was measured in triplicate at the same time as the samples. Dilution space was determined as the activity of injected isotope divided by the activity of the post-equilibration sample. TBW was estimated from the dilution space using a previously derived equation for pinnipeds (Bowen and Iverson, 1998). Fat mass was determined from TBW using the equation:

$M_{F}=M_{T}-1.37(T B W)$

(Iverson et al., 1993), where $M_{F}$ is the fat mass of the seal (in $\mathrm{kg}$ ) and $\mathrm{M}_{\mathrm{T}}$ is the total body mass ( $\mathrm{kg}$ ). Daily energy expenditure (DEE) was estimated from mass and body composition changes. The energy produced through nutrient catabolism was calculated assuming protein or lipid lost by the male yielded 17.99 and $39.33 \mathrm{~kJ} / \mathrm{g}$, respectively (Costa, 1987). For these calculations, lean tissue loss was assumed to be $73 \%$ water and $27 \%$ protein.

\subsection{Hormone and metabolite analyses}

Hormone concentrations were measured by radioimmunoassay or enzyme immunoassay using commercially available kits: glucagon, growth hormone, insulin, leptin (multispecies kit, Linco Research Inc., St. Charles, MO, USA), cortisol, $\mathrm{tT}_{3}, \mathrm{tT}_{4}$ (DPC, Los Angeles, CA, USA), ghrelin (rabbit anti-human; Phoenix pharmaceuticals, Belmont, CA) and IGF-1 (DSL, Webster, TX, USA). Each assay had been validated previously for use with northern elephant seal samples (Houser and Costa, 2001; Ortiz et al., 2001a, 2001b, 2003; Champagne et al., 2005). Recognizing that the leptin antibody was raised against human leptin and that human leptin standards were used in the assay, immunoreactive NES leptin concentrations are expressed in

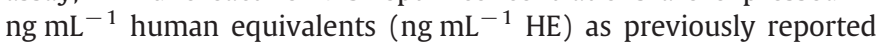
(Ortiz et al., 2001a, 2001b). All samples were analyzed in duplicate and run in a single assay with intra-assay percent coefficient of variability of less than $8 \%$ for all assays. Glucose and blood urea nitrogen (BUN) were measured in duplicate on a Cobas Mira autoanalyzer (Roche Diagnostic Systems, Montclair, NJ, USA). Non-esterified fatty acids (NEFA; Wako, Richmond, VA, USA) and beta-hydroxybutyrate 
Table 1

Mean $( \pm$ SEM) body mass, body fat, and serum metabolites sampled at early and late periods during the breeding fast. Asterisks $\left(^{*}\right)$ denote significant differences in late fast samples when compared to the early fast $(\mathrm{p}<0.05)$.

\begin{tabular}{lcc}
\hline & Early Fast & Late Fast \\
\hline Body mass $(\mathrm{kg})$ & $1481 \pm 65$ & $1137 \pm 53^{*}$ \\
Body fat $(\%)$ & $29.5 \pm 0.5$ & $20.4 \pm 0.7^{*}$ \\
$\beta$-HBA $(\mu \mathrm{M})$ & $234 \pm 11$ & $365 \pm 12^{*}$ \\
BUN $(\mathrm{mM})$ & $10.2 \pm 0.3$ & $10.5 \pm 0.3$ \\
Glucose $(\mathrm{mM})$ & $6.0 \pm 0.3$ & $5.5 \pm 0.4$ \\
NEFA $(\mathrm{mM})$ & $0.78 \pm 0.1$ & $0.83 \pm 0.6$ \\
\hline
\end{tabular}

( $\beta$-HBA; Sigma-Aldrich, St. Louis, MO, USA) were measured in duplicate by enzymatic colorimetric assays.

\subsection{Data analysis}

Statistics were performed using SAS v.8 with a significance level of $\mathrm{p}<0.05$. Comparisons between samples were made using paired $\mathrm{t}$ tests. When necessary variables were log transformed to meet the assumptions of parametric statistics. Means are presented as \pm 1 SEM.

\section{Results}

\subsection{Mass loss, body composition change, and energy expenditure}

A detailed analysis of energy expenditure and breeding behavior from this study has been published previously (Crocker et al., 2012). Here we summarize energy expenditure and body composition data to provide a context for comparisons of hormones and metabolites. Eighteen of the seals were recaptured at a mean interval of $44.1 \pm 1.4$ days, or $54 \%$ of the average estimated time on shore ( $81 \pm 3$ days). On average, subjects were estimated to have been fasting $17 \pm 2$ days at the first sample. Mean mass of study animals at initial capture was $1481 \pm 65 \mathrm{~kg}$. Mean percentage of mass lost over the measurement period was $23.1 \pm 0.6 \%$ or an average loss of $7.8 \pm 0.6 \mathrm{~kg} \mathrm{day}^{-1}$. Body fat declined from $29.5 \pm 0.5 \%$ to $20.4 \pm 0.7 \%$ body fat between the first and second measurements. Mean daily energy expenditure (DEE) was $195 \pm 12 \mathrm{MJ} \mathrm{day}^{-1}$. Males met $7.0 \pm 0.6 \%$ of their energy expenditure through protein catabolism and this value declined with the initial proportion of body fat $\left(\mathrm{r}^{2}=0.55, \mathrm{p}<0.001\right)$.

\subsection{Metabolites}

Mean $\beta$-HBA increased from $234 \pm 11 \mu \mathrm{M}$ early in breeding to $365 \pm 12 \mu \mathrm{M}$ late in breeding $(\mathrm{p}<0.001$; Table 1$)$. Mean serum glucose, NEFA, and BUN did not change significantly across the breeding fast (Table 1). NEFA was not correlated with body fat mass at either early or late sampling periods $(p=0.43, p=0.09$ ). Mean BUN was not correlated with the proportion of metabolism from protein

Table 2

Mean $( \pm$ SE) serum hormone concentrations sampled at early and late periods during the breeding fast. Asterisks $\left({ }^{*}\right)$ denote significant differences in late fast samples when compared to the early fast $(\mathrm{p}<0.05)$.

\begin{tabular}{|c|c|c|}
\hline Hormone & Early Fast & Late Fast \\
\hline Insulin $\left(\mathrm{pg} \mathrm{mL}^{-1}\right)$ & $73.9 \pm 3.5$ & $68.3 \pm 2.0$ \\
\hline Glucagon $\left(\mathrm{pg} \mathrm{mL}^{-1}\right)$ & $35.9 \pm 3.5$ & $49.9 \pm 2.9^{*}$ \\
\hline Insulin:glucagon molar ratio & $1.27 \pm 0.10$ & $0.84 \pm 0.06^{*}$ \\
\hline Growth hormone (ng mL $\mathrm{m}^{-1}$ ) & $2.3 \pm 0.3$ & $1.3 \pm 0.1^{*}$ \\
\hline Insulin-like growth factor-1 $\left(\mathrm{ng} \mathrm{mL}^{-1}\right)$ & $527.2 \pm 55.2$ & $447.8 \pm 52.5$ \\
\hline Ghrelin $\left(\mathrm{pg} \mathrm{mL}^{-1}\right)$ & $325.5 \pm 25.8$ & $350.2 \pm 32.0$ \\
\hline Leptin $\left(\mathrm{ng} \mathrm{mL}^{-1} \mathrm{HE}\right)$ & $5.7 \pm 0.3$ & $5.1 \pm 0.2^{*}$ \\
\hline Total tri-iodothyronine $\left(\mathrm{ng} \mathrm{mL}^{-1}\right)$ & $1.33 \pm 0.25$ & $1.27 \pm 0.21$ \\
\hline Total thyroxine $\left(\mathrm{ng} \mathrm{mL}^{-1}\right)$ & $12.0 \pm 1.3$ & $15.0 \pm 2.2$ \\
\hline Cortisol (ng mL $\left.{ }^{-1}\right)$ & $83 \pm 7$ & $77 \pm 9$ \\
\hline
\end{tabular}

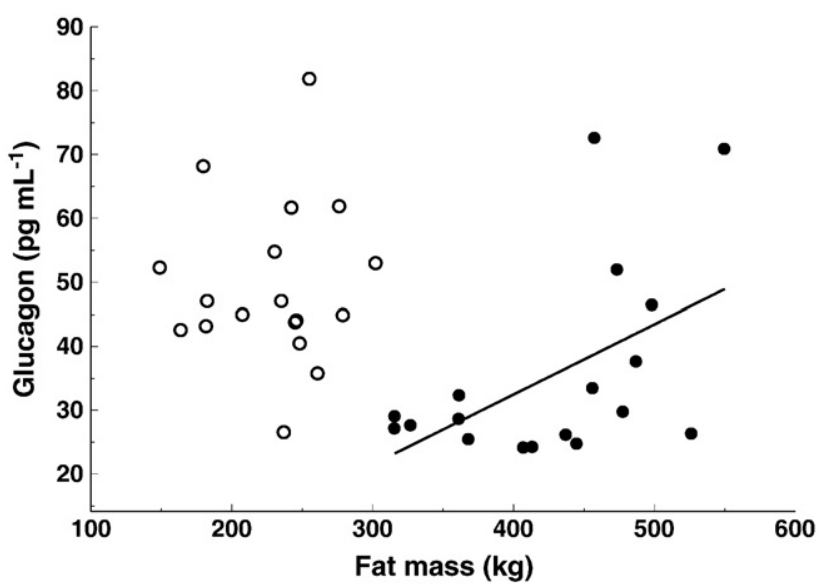

Fig. 1. Relationship between fat mass and plasma glucagon levels. Closed circles are samples from early in the breeding fast $\left(\mathrm{y}=-11.40+0.110 \mathrm{x} ; \mathrm{r}^{2}=0.27, \mathrm{~F}_{1,15}=5.9\right.$, $p=0.03$ ). Open circles are samples from late in the breeding fast.

catabolism $(\mathrm{p}=0.61)$. BUN was not correlated with body composition at either sampling period $(\mathrm{p}>0.05)$.

\subsection{Hormones}

Glucagon increased 39\% between the early (35.9 $\left.\mathrm{pg} \mathrm{mL}^{-1}\right)$ and late $\left(49.9 \mathrm{pg} \mathrm{mL}^{-1}\right)$ sampling periods $(\mathrm{p}=0.003)$; however, insulin did not change across the measurement period and remained relatively low (Table 2). Insulin to glucagon molar ratio ( $\mathrm{I} / \mathrm{G}$ ) decreased $34 \%(p<0.001)$ across the breeding period (Table 2$)$. Glucagon varied significantly and positively with fat mass in the early sampling period $\left(r^{2}=0.23, p=0.04\right)$, but the relationship was not significant in the late sampling period (Fig. 1).

The $43 \%$ decrease $(p=0.004)$ in GH between early $\left(2.3 \mathrm{ng} \mathrm{mL}^{-1}\right)$ and late $\left(1.3 \mathrm{ng} \mathrm{mL}^{-1}\right)$ sampling periods was not associated with a concomitant decrease in IGF-1 (Table 2). GH varied significantly and negatively with fat mass in the early sampling period $\left(r^{2}=0.29\right.$, $\mathrm{p}=0.02$ ), but the relationship was not significant in the late sampling period (Fig. 2). Although ghrelin concentrations did not change significantly over the measurement interval, GH increased significantly with ghrelin levels in the early sampling period (Fig. $3 ; r^{2}=0.25$, $p=0.04)$. Leptin decreased $11 \%(p=0.04)$ over the measurement interval (Table 2 ), but did not vary with fat mass or percent fat mass in either sampling period ( $\mathrm{p}>0.05$ ). Thyroid hormones (tT3, tT4, and tT4:tT3) and cortisol did not change significantly across the breeding

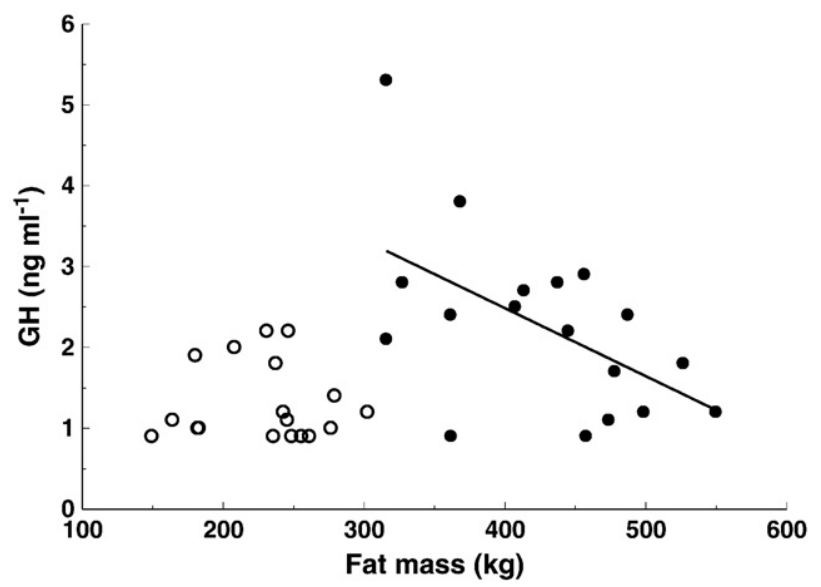

Fig. 2. Relationship between fat mass and plasma GH levels. Closed circles are samples from early in the breeding fast $\left(y=5.75-0.008 x ; r^{2}=0.28, F_{1,15}=6.3, p=0.02\right)$. Open circles are samples from late in the breeding fast. 


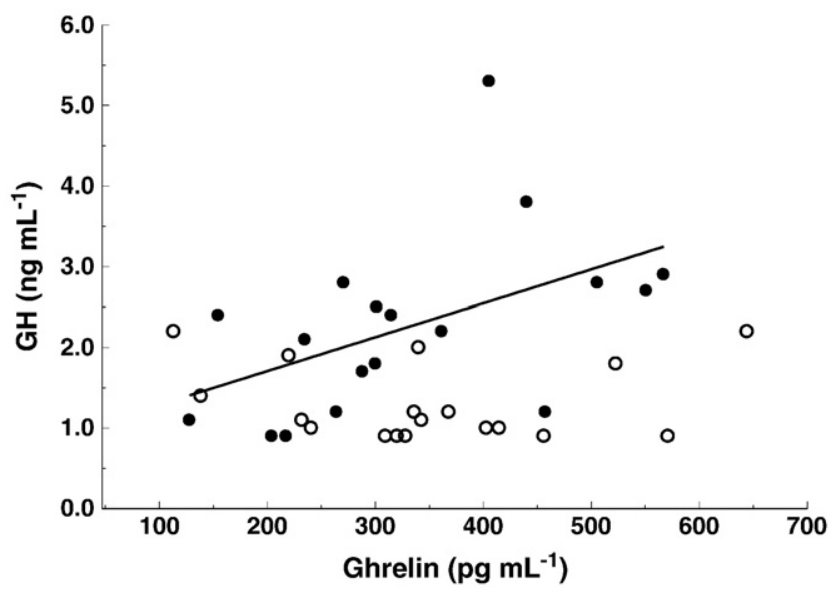

Fig. 3. Relationship between plasma ghrelin and GH values. Closed circles are samples from early in the breeding fast $\left(y=0.96+0.0034 x ; r^{2}=0.31, F_{1,15}=6.7, p=0.02\right)$. Open circles are samples from late in the breeding fast.

season (Table 2); however cortisol varied negatively with body mass within the late sample $\left(r^{2}=0.25, p=0.04\right)$.

There were no significant relationships between any of the measured hormones and measured metabolites in the early or late samples $(p>0.05)$. However, the DEE was directly related to the change in tT3 between the early and late sampling periods $\left(r^{2}=0.25\right.$, $\mathrm{p}=0.03$ ), as was the percentage of the DEE derived from protein (Fig. $4 ; \mathrm{r}^{2}=0.53, \mathrm{p}<0.001$ ).

\section{Discussion}

Numerous differences in hormone responses to the fast between breeding males, lactating or developing conspecifics, and other fasting-adapted species suggest alterations in hormone regulation of metabolism to promote protein sparing during extended fasting despite high activity and DEE. These differences include alterations in the response of thyroid hormones, $\mathrm{GH}$ and cortisol to fasting duration and suggest alterations in metabolic regulation in response to sex, development and physiological state.

Fasting is generally associated with down-regulation of metabolic rate via suppression of the thyroid axis (Spencer et al., 1983; Blake et al., 1991; Boelen et al., 2008). We found no changes in total thyroid hormones across the fast. However the ability to maintain or suppress thyroid hormones had positive impacts on protein sparing among individuals. Individuals with higher DEE exhibited elevations

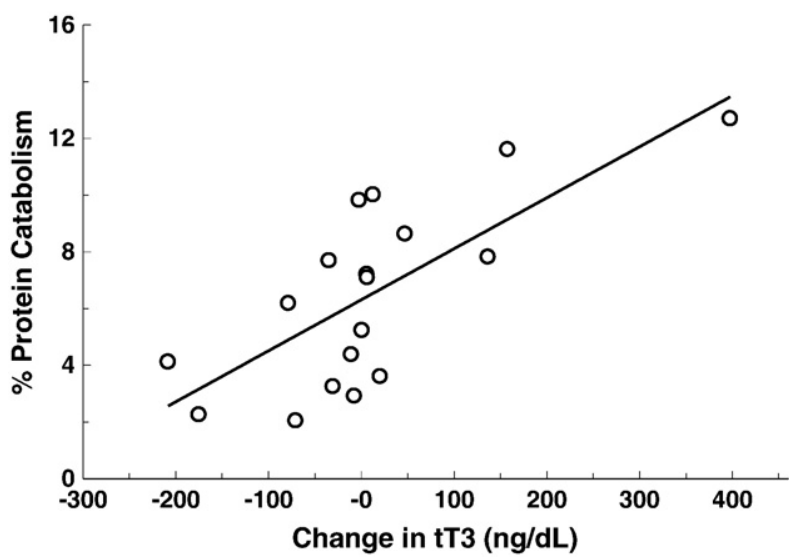

Fig. 4. Relationship between the changes in total triiodothyronine (tT3) and the percent contribution of protein to energy metabolism over the measurement interval $\left(\mathrm{y}=6.3+0.018 * \Delta \mathrm{tT}_{3} ; \mathrm{r}^{2}=0.53, \mathrm{~F}_{1,15}=17.9, \mathrm{p}<0.001\right)$. Protein catabolism was estimated from changes in mass and body composition. of thyroid across the fast and this was associated with reductions in protein sparing. Thyroid hormones have been demonstrated to vary as a function of age and physiological condition in phocid seals (Boily, 1996; Haulena et al., 1998; Sormo et al., 2005; Stokkan et al., 1995; Woldstad and Jenssen, 1999; Yochem et al., 2008; Bennett et al. 2012). Values of tT3 in fasting adult male elephant seals are comparable to values observed in non-molting, adult members of other species of phocid seal, regardless of whether they are fasting or intermittently feeding (see Haulena et al., 1998 for a table providing thyroid hormone values for phocid seals by age and reproductive condition). However, fed yearling elephant seals demonstrated tT3 levels nearly half, and tT4 levels nearly double, that observed in fasting adult male elephant seals (Yochem et al., 2008). Studies in weaned elephant seals undergoing long-term fasts revealed relatively stable $\mathrm{tT}_{3}$ across the fast, but an increase in $\mathrm{tT}_{4}$ between the first 2 weeks of fasting and the eighth week of fasting (Ortiz et al., 2001a; 2003). In breeding adult males thyroid hormones did not change significantly across the fast, but the relative difference in thyroid hormone levels between fasting pups and adult males was comparable to the differences observed between adult males and fed yearlings. Despite the 1.7 to 2.7-fold greater concentration of tT3 in fasting adult males, tT4 in fasting pups was 1.3 to 2.5-fold greater (Ortiz et al., 2001a, 2003). Difference in thyroid hormones observed between fasting pups, fed yearlings and concomitantly fasting and breeding adult males could reflect the high rate of energy expenditure by the breeding males. A higher rate of T4 deiodination to T3 to support the increase in energy expenditure would explain the differences in hormone levels between the active adults and the relatively quiescent weanlings and yearlings. Conversely, similar levels of thyroid hormones between young seals, independent of feeding state, may reflect the similar utilization of fuel substrates during fasting and feeding in this fasting-adapted species, i.e. a pre-adaptation to fasting due to a reliance on lipid catabolism and protein sparing while fasting and feeding (Kirby and Ortiz, 1994; Houser and Costa, 2001).

Leptin increases lipid oxidation and reduces triacylglycerol synthesis. In mammals, the progression of food deprivation generally results in a decrease in leptin within a few days of the cessation of food consumption (Kolaczynski et al., 1996; Mustonen et al., 2005). This in turn suppresses the thyroid axis to conserve energy (Boelen et al., 2008) and dis-inhibits the production of neuropeptide Y (NPY) resulting in the stimulation of feeding (Williams et al., 2004). Ghrelin antagonizes the action of leptin and stimulates the production of NPY (Shintani et al., 2001). Circulating levels of leptin as determined by RIA range from $4.0-39.5 \mathrm{ng} / \mathrm{mL}$ in non-fasting humans, $2.4-12.0 \mathrm{ng} /$ $\mathrm{mL}$ in humans fasting for several days, and may drop as low as $1.7 \mathrm{ng} / \mathrm{mL}$ in fasts in excess of 40 days (Boden et al., 1996; Kolaczynski et al., 1996; Weigle et al., 1997; Korbonits et al., 2007). In fed and fasting states, leptin demonstrates a positive relationship to obesity in humans and other mammals (Florant et al., 1986; Boden et al., 1996; Kolaczynski et al., 1996; Weigle et al., 1997). In mammals that undergo fasts as part of their natural history, leptin ranges from 2.8 to $4.3 \mathrm{ng} / \mathrm{mL}$ during the fast with nadirs typically occurring late in the fast (Florant et al., 1986; Nieminen et al., 2002; Fuglei et al., 2004; Mustonen et al., 2005; Donahue et al., 2006). Levels of ghrelin in mammals undergoing natural fasts show broader species variability - values range from approximately $2-3 \mathrm{ng} / \mathrm{mL}$ in fasting raccoon dogs (Nycteretes procyonides); (Nieminen et al., 2002), from 38.8 to $61.4 \mathrm{pg} / \mathrm{mL}$ in fasting minks (Mustela vison; Mustonen et al., 2005), and from approximately $175-210 \mathrm{pg} / \mathrm{mL}$ in arctic foxes (Alopex lagopus; Fuglei et al., 2004). Levels of leptin (5.1-5.7 ng/ $\mathrm{mL}$ ) and ghrelin $(325.5-350.2 \mathrm{pg} / \mathrm{mL})$ in breeding male elephant seals are consistent with the proposed inverse antagonistic relationship between ghrelin and leptin and may function to suppress the drive to forage in this fasting species (Shintani et al., 2001) while optimizing rates of lipid oxidation. 
Although a significant decrease in leptin levels was detected in the fasting adult males, it was not associated with increased suppression of thyroid hormones. Fasting male minks demonstrate a comparable pattern to that of breeding adult male elephant seals with leptin rapidly declining early in the fast but remaining uncorrelated with thyroid hormone levels throughout the fast (Mustonen et al., 2005). Similarly, observations in fasting raccoon dogs and blue foxes (Alopex logopus) showed that changes in leptin and thyroxine levels were uncoupled, especially late in the fasting period (Nieminen et al., 2001). In contrast, fasting weanling elephant seals show no variation in leptin across 8 weeks of fasting and an increase in tT4 (Ortiz et al., 2003). Collectively, the data for fasting pups and adults suggest that leptin does not influence thyroid hormones in this model of protracted food deprivation. The consistency in this uncoupling across multiple species may signify a common mechanism by which metabolic expenditure is controlled in species that incorporate fasting as part of their natural history. However, we also note there is evidence that fasting-adapted penguins lack leptin activity while maintaining the tissue receptor (Yosefi et al., 2010) and that the leptin gene is under positive selection in phocids (Yu et al., 2011), suggesting the potential for unique physiological roles in this taxa.

Adult male elephant seals show a significant reduction in GH that parallels a reduction in leptin across the breeding fast. This relationship has been suggested as causally related in rodents, with the reduction in leptin suppressing the release of GH via action on NPY secretion (Vuagnat et al., 1998). Suppression of GH while fasting should reduce lipolysis and increase hepatic glucose production (Sakharova et al., 2008), both of which would appear maladaptive during a long duration fast. However, GH has other anabolic actions that may not be permissible given the catabolic state of the male elephant seal during the energetically costly act of breeding. Reductions in leptin may have a suppressive effect on GH which may in turn permit greater efficacy of other lipolytic hormones at the cost of greater rates of glucose production. The greater loss of lean tissue in breeding male elephant seals relative to that observed in post-molt, fasting weanlings (Houser and Costa, 2001) and simultaneously fasting and lactating females (Crocker et al., 1998) may support this proposition provided lean tissue catabolism supports gluconeogenesis. However, high rates of glucose recycling, as suggested in weaned pups and lactating females (Champagne et al., 2005; 2006), may reduce impacts of GH suppression on commitment of amino acids to glucose production.

Ghrelin is a gastric-derived protein that can stimulate the secretion of GH (Kojima et al., 1999), stimulate feeding (Nakazato et al., 2001) and reduce insulin secretion (Broglio et al., 2001). Ghrelin has been identified as the hormone responsible for hypersecretion of GH in fasting humans (Muller et al., 2002) and an increase in ghrelin was observed across the post-weaning fast in elephant seal pups (Ortiz et al., 2003). Ghrelin was positively correlated with GH during the early sampling period in this study suggesting that it potentially remains a GH secretagogue early in the fast. Despite the maintenance of relatively high concentrations ( $>2$-times fasting pup concentrations) of ghrelin throughout the measurement period, GH concentrations decreased by the late sampling period suggesting that the ability of ghrelin to stimulate GH may have been lost. Fasting induces a state of hepatic GH resistance characterized by GH hypersecretion and low serum IGF levels (Nørrelund et al., 1999). Since circulating IGF-1 directly inhibits pituitary $\mathrm{GH}$ secretion and also stimulates hypothalamic somatotropin release-inhibiting factor secretion (Berelowitz et al., 1981), fasting-associated reduction in IGF-I concentrations may mediate increased GH secretion by loss of feedback inhibition. IGF-1 did not fall across the fast in male elephant seals, potentially removing one cue for enhanced GH secretion.

In mammals and birds, glucose homeostasis during fasting is predominantly controlled by interactions between insulin and glucagon, with decreasing $\mathrm{I} / \mathrm{G}$ ratios associated with increased substrate mobilization and stimulation of gluconeogenesis (Cuendet et al., 1975;
Hazelwood 1984). Observations in weaned elephant seal pups suggest that declining $\mathrm{I} / \mathrm{G}$ ratios while fasting result from increased glucagon levels coupled with either declining or stable insulin levels (Ortiz et al., 2003; Champagne et al., 2005). In contrast, lactating female elephant seals achieve reductions in $\mathrm{I} / \mathrm{G}$ ratios while fasting through suppression of insulin alone (Champagne et al., 2006; Houser et al., 2007). In both cases this change is associated with stable rates of gluconeogenesis. Breeding adult males show a similar pattern to fasting pups with declining $\mathrm{I} / \mathrm{G}$ ratios resulting from increased glucagon levels and maintenance of high plasma glucose concentrations across the fast (although at lower levels than observed in fasting pups or fasting and lactating females). Nevertheless, plasma glucagon concentrations were low compared to non-fasting adapted mammals (e.g. Boyle et al., 1989) and fasting adapted birds (e.g. Cherel et al., 1988), and were lower (e.g. Florant et al., 1986) or similar (e.g. Mustonen et al., 2005) to that observed in other fasting adapted mammals.

Insulin has a lipogenic effect via facilitation of hepatic fatty acid synthesis from glucose and uptake of glucose for glycerol formation in adipocytes, as well as an anti-lipolytic effect via inhibition of intracellular triglyceride hydrolization. Several investigations have suggested that low insulin levels in fasting-adapted species are a critical adaptation to facilitate high levels of lipid mobilization during fasting (e.g. Cherel et al., 1988). In contrast, cortisol, GH and leptin are known to inhibit lipogenesis and/or stimulate lipolysis (Goodman et al., 1968; Bergendahl et al., 1996; Kersten, 2001). In this study, cortisol and insulin did not change during the fasting period and GH and leptin decreased significantly. These patterns of change would appear inconsistent with the idea of enhanced lipolysis and lipid oxidation with the progression of fasting. Plasma NEFA, an index of rates of lipolysis, were stable across the fast in males. In contrast, $\mathrm{GH}$, cortisol and NEFA levels increase across the fast in lactating females (Champagne et al., 2006; Houser et al., 2007; Crocker, unpublished data). Despite this increase, rates of lipolysis declined dramatically across the fast in females as adipose tissue proportions were reduced (Houser et al., 2007). NEFA were uncoupled from rates of lipolysis in females suggesting that rates of fatty acid re-esterification and oxidation varied significantly across the fast. Decreasing GH levels late in the current study may reflect changing needs for fatty acid mobilization as energy expenditure declines late in the breeding season.

The one measured metabolite that changed significantly over the breeding fast was the ketoacid, $\beta$-HBA. Although this metabolite increased significantly, its concentration remained extremely low when compared to other species undergoing similar duration fasts (Cherel et al., 1988; Baumber et al., 1971) and was also lower than observed in fasting elephant seal pups and lactating females. Plasma $\beta$-HBA concentration increases through the first 50 days of fasting in both elephant seal (Castellini and Costa, 1990; Champagne et al., 2005) and grey seal (Halichoerus grypus; Nordøy and Blix, 1991) weanlings. This pattern was also observed in the adult males of this study, although the $\beta$ HBA concentration was less than $50 \%$ that observed in weanling seals, independent of time fasting. Prior reports of mean $\beta$-HBA in lactating females indicate an increase from $264 \mu \mathrm{M}$ early in lactation to $345 \mu \mathrm{M}$ at the end of lactation (Champagne et al., 2006), which is similar to the values and trend reported for fasting males in this study. In comparison to both elephant seal studies, ketone levels in fasting penguins were 15 times as high at the end of stage 2 fasting (Cherel and LeMaho, 1988). The marginal accumulation of ketoacids despite a largely fat based metabolism and long fasting duration possibly suggests either high rates of ketoacid utilization that are independent of plasma levels or reduced ketogenesis. The elevation of $\beta-\mathrm{HBA}$ is consistent with the increase in the important ketogenic hormone, glucagon; however, the two variables were not correlated. Similarly, an increase in $\beta$-HBA corresponded to a significant reduction in leptin. This relationship has been observed in fasting humans (Kolaczynski et al., 1996), but a causal link between the two has not been determined. 
Breeding male elephant seals were effective at sparing protein despite high rates of energy expenditure. Regulators of muscle protein turnover include insulin, glucagon, glucocorticoids, thyroid hormones, GH and IGF-1 (Goldberg et al., 1980; Koea et al., 1992). Although low insulin levels may be required for net proteolysis, previous studies have not suggested a role for insulin in regulating net proteolysis during extended fasting (Goodman et al., 1980; Cherel et al., 1992). Similarly, IGF1 and GH affect protein synthesis and increases in these hormones could reflect a progressive shift in muscle sparing. However, no such changes were noted in this study. Indeed, GH decreased and glucagon increased with fasting suggesting a greater mobilization of protein stores, possibly for the purpose of meeting the demands of glucose oxidation. In addition, the correlation of individual changes in $\mathrm{T}_{3}$ with proportional protein catabolism is consistent with thyroid impacts on protein turnover. The correlation of both variables with DEE suggests that basal levels of energy expenditure may impact protein sparing during the breeding fast and that there may be a tight coupling between the hormonal regulation of protein catabolism and body composition.

In summary, breeding northern elephant seal males exhibited metabolic homeostasis despite long duration, high energy expenditure fasts. Measurements support the general regulatory model that low insulin levels and low I/G ratios are associated with the fasting catabolic state, primarily in the form of fat degradation. Similarly, relationships between ghrelin and leptin seem to be consistent with the suppression of appetite. An increase in glucagon and a notable direct relationship between changes in $\mathrm{tT}_{3}$ and the contribution of protein to the DEE support the concept of increased protein mobilization. Several other differences were apparent in comparison to similar duration fasts in weaned elephant seal pups, including the stabilization of cortisol levels and the unexpected suppression of GH across the fast. These differences are possibly a result of the high levels of energy expenditure in breeding males and/or the adaptations associated with ontogeny in elephant seal pups and suggest alterations in metabolic regulation relative to life history stage and nutrient demands.

\section{Acknowledgments}

We would like to thank L. Pagarigan and B. Sherman for their assistance with the lab analyses. We appreciate the efforts of many student volunteers from UCSC for helping in the field. This work was performed at the University of California Natural Reserve System, Año Nuevo Reserve. We thank G. Strachan and the rangers of the Año Nuevo Reserve for allowing us access to the animals and for their assistance in the field. This project was supported by grant nos. 0213095 and 0818018 from the National Science Foundation. Any opinions and conclusions or recommendations expressed in this material are those of the authors and do not necessarily reflect the views of the National Science Foundation.

\section{References}

Ahima, R.S., Prabakaran, D., Mantzoros, C., Qu, D., Lowell, B., Maratos-Flier, E., Flier, J.S 1996. Role of leptin in the neuroendocrine response to fasting. Nature 382, 250-252. Anderson, S.S., Fedak, M.A., 1985. Grey seal males: energetic and behavioural links between size and sexual success. Anim. Behav. 33, 829-838.

Baumber, J., South, F.E., Ferren, L., Zatzman, M.L., 1971. A possible basis for periodic arousals during hibernation: accumulation of ketone bodies. Life Sci. 10, 463-467.

Bennett, K.A., Moss, S.E.W., Pomeroy, P., Speakman, J.R., Fedak, M.A., 2012. Effects of handling regime and sex on changes in cortisol, thyroid hormones and body mass in fasting grey seal pups. Com. Biochem. Phys. A 161, 69-76.

Berelowitz, M., Szabo, M., Frohman, L.A., Firestone, S., Chu, L., Hintz, R.L., 1981. Somatomedin- $\mathrm{C}$ mediates growth hormone negative feedback by effects on both the hypothalamus and the pituitary. Science 212, 1279-1281.

Bergendahl, M., Vance, M.L., Iranmanesh, A., Thorner, M.O., Veldhuis, J.D., 1996. Fasting as a metabolic stress paradigm selectively amplifies cortisol secretory burst mass and delays the time of maximal nyctohemeral cortisol concentrations in healthy men. J. Clin. Endocrin. Metab. 81, 692-699.

Blake, N.G., Eckland, D.J., Foster, O.J., Lightman, S.L., 1991. Inhibition of hypothalamic thyrotropin-releasing hormone messenger ribonucleic acid during food deprivation. Endocrinology 129, 2714-2718.
Boden, G., Chen, X., Mozzoli, M., Ryan, I., 1996. Effect of fasting on serum leptin in normal human subjects. J. Clin. Endocrinol. Metab. 81, 3419-3423.

Boelen, A., Wiersinga, W.M., Fliers, E., 2008. Fasting-induced changes in the hypothalamuspituitary-thyroid axis. Thyroid 18, 123-129.

Boily, P., 1996. Metabolic and hormonal changes during the molt of captive gray seals, Halichoerus grypus. Am. J. Physiol. 270, R1051-R1058.

Bowen, W.D., Iverson, S.J., 1998. Estimation of total body water in pinnipeds using hydrogen-isotope dilution. Physiol. Biochem. Zool. 71, 329-332.

Boyle, P.J., Shah, S.D., Cryer, P.E., 1989. Insulin, glucagon and catecholamines in prevention of hypoglycemia during fasting. Am. J. Physiol. 256, E651-E661.

Broglio, F., Arvat, E., Benso, A., Gottero, C., Muccioli, G., Papotti, M., van der Lely, A.J., Deghenghi, R., Ghigo, E., 2001. Ghrelin, a Natural GH Secretagogue Produced by the Stomach, Induces Hyperglycemia and Reduces Insulin Secretion in Humans. J. Clin. Endocrin. Metab. 86, 5083-5086.

Cahill, G.F., 1978. Famine symposium: physiology of acute starvation in man. Ecolog. Food Nutr. 6, 221-230.

Castellini, M.A., Costa, D.P., 1990. Relationships between plasma ketones and fasting duration in neonatal elephant seals. Am. J. Physiol. 259, R1086-R1089.

Castellini, M.A., Rea, L.D., 1992. The biochemistry of natural fasting at its limits. Cell. Mol. Life Sci. 48, 575-582.

Champagne, C.D., Houser, D.S., Crocker, D.E., 2005. Glucose production and substrate cycle activity in a fasting adapted animal, the northern elephant seal. J. Exp. Biol. 208, 859-868.

Champagne, C.D., Houser, D.S., Crocker, D.E., 2006. Glucose metabolism during lactation in a fasting animal, the northern elephant seal. Am. J. Physiol. 291, R1129-R1137.

Cherel, Y., LeMaho, Y., 1985. Five months of fasting in king penguin chicks: body mass loss and fuel metabolism. Am. J. Physiol. 249, R387-R392.

Cherel, Y., LeMaho, Y., 1988. Changes in body mass and plasma metabolites during short-term fasting in the king penguin. Condor 90, 257-258.

Cherel, Y., Robin, J.P., Walch, O., Karmann, H., Netchitailo, P., Le Maho, Y., 1988. Fasting in king penguin. I. Hormonal and metabolic changes during breeding. Am. J. Physiol. 254, R170-177.

Cherel, Y., Robin, J.P., Heitz, A., Calgari, C., Le Maho, Y., 1992. Relationships between lipid availability and protein utilization during prolonged fasting. J. Comp. Physiol. B 162, 305-311.

Cherel, Y., Omari, B.E., Le Maho, Y., Sabourea, M., 1995. Protein and lipid utilization during fasting with shallow and deep hypothermia in the European hedgehog (Erinaceus europaeus). J. Comp. Physiol. B 164, 653-658.

Costa, D.P., 1987. Isotopic methods for quantifying material and energy intake of freeranging marine mammals. In: Huntley, A.C., Costa, D.P., Worthy, G.A.J., Castellini, M.A. (Eds.), Approaches to Marine Mammal Energetics. Society for Marine Mammalogy, pp. 43-66.

Crocker, D.E., Webb, P.M., Costa, D.P., Le Boeuf, B.J., 1998. Protein catabolism and renal function in lactating northern elephant seals. Physiol. Zool. 71, 485-491.

Crocker, D.E., Houser, D.S., Webb, P.M., 2012. Impact of body reserves on energy expenditure, water flux, and mating success in breeding male northern elephant seals. Physiol. Biochem. Zool. 85, 11-20.

Cuendet, G.S., Loten, E.G., Cameron, D.P., Renold, A.E., Marliss, E.B., 1975. Hormone-substrate responses to total fasting in lean and obese mice. Am. J. Phys. 228, 276-283.

Deutsch, C.J., Haley, M.P., Le Boeuf, B.J., 1990. Reproductive effort of male northern elephant seals: estimates from mass loss. Can. J. Zool. 68, 2580-2593.

Deutsch, C., Costa, D.P., Le Boeuf, B.J., 1994. Sex differences in reproductive effort in northern elephant seals. In: Le Boeuf, BJ. Laws, R.M. (Eds.), Elephant Seals: Population Ecology, Behavior, and Physiology. University of California Press, Berkeley, pp. 169-210.

Donahue, S.W., Galley, S.A., Vaughan, M.R., Patterson-Buckendahl, P., Demers, L.M., Vance, J.L., McGee, M.E., 2006. Parathyroid hormone may maintain bone formation in hibernating black bears, Ursus americanus to prevent disuse osteoperosis. J. Exp. Biol. 209, 1630-1638.

Florant, G.L., Hoo-Paris, R., Castex, C., Bauman, W.A., Sutter, B.C., 1986. Pancreatic A and $B$ cell stimulation in euthermic and hibernating marmots, Marmota flaviventris: effects of glucose and arginine administration. J. Comp. Physiol. B 156, 309-314.

Fowler, M.A., Champagne, C.D., Houser, D.S., Crocker, D.E., 2008. Hormonal regulation of glucose clearance in lactating northern elephant seals (Mirounga angustirostris). J. Exp. Biol. 211, 2943-2949.

Fuglei, E., Mustonen, A.-M., Nieminen, P., 2004. Effects of season, food deprivation and re-feeding on leptin, ghrelin and growth hormone in arctic foxes, Alopex lagopus on Svalbard, Norway. J. Comp. Physiol. B 174, 157-162.

Goldberg, A.L., Tischler, M., DeMartino, G., Griffin, G., 1980. Hormonal regulation of protein degradation and synthesis in skeletal muscle. Fed. Proc. 39, 31-36.

Goodman, H.G., Grumbach, M.M., Kaplan, S.L., 1968. Growth and growth hormone - a comparison of isolated growth-hormone deficiency and multiple pituitary-hormone deficiencies in 35 patients with idiopathic hypopituitary dwarfism. N. Engl. J. Med. 278, 57-68.

Goodman, M.N., Larsen, P.R., Kaplan, M.M., Aoki, T.T., Young, V.R., Ruderman, N.B., 1980. Starvation in the rat. II. Effect of age and obesity on protein sparing and fuel metabolism. Am. J. Physiol. 239, E277-E286.

Haley, M.P., Deutsch, C.J., Le Boeuf, B.J., 1994. Size, dominance and copulatory success in male northern elephant seals, Mirounga angustirostris. Anim. Behav. 48, 1249-1260.

Haulena, M., D. St. Aubin, Duignan, P.J., 1998. Thyroid hormone dynamics during the nursing period in harbour seals, Phoca vitulina. Can. J. Zool. 76, 48-55.

Hazelwood, R.L., 1984. Pancreatic hormones, insulin/glucagon molar ratios, and somatostatin as determinants of avian carbohydrate metabolism. J. Exp. Zool. 232, 647-652. 
Henry, C.J., Rivers, J.P., Payne, P.R., 1988. Protein and energy metabolism in starvation reconsidered. Eur. J. Clin. Nutr. 42, 543-549.

Houser, D.S., Costa, D.P., 2001. Protein catabolism in suckling and fasting northern elephant seal pups, Mirounga angustirostris. J. Comp. Physiol. B 171, 635-642.

Houser, D.S., Champagne, C.D., Crocker, D.E., 2007. Lipolysis and glycerol gluconeogenesis in simultaneously fasting and lactating northern elephant seals. Am. J. Physiol. 293, R2376-R2381.

Iverson, S.J., Bowen, W.D., Boness, D.J., Oftedal, O.T., 1993. The effect of maternal size and milk energy output on pup growth in grey seals, Halichoerus grypus. Physiol. Zool. 66, 61-88.

Kersten, S., 2001. Mechanisms of nutritional and hormonal regulation of lipogenesis. EMBO Rep. 21, 282-286

Kirby, V.L., Ortiz, C.L., 1994. Hormones and fuel regulation in fasting elephant seals. In: Le Boeuf, B.J., Laws, R.M. (Eds.), Elephant Seals: Population Ecology, Behavior, and Physiology. University of California Press, Berkeley, pp. 374-386.

Koea, J.B., Doublas, R.G., Breier, B.H., Shaw, J.H., Gluckman, P.D., 1992. Synergistic effect of insulin-like growth factor-I administration on the protein-sparing effects of total parenteral nutrition in fasted lambs. Endocrinology 131, 643-648.

Kojima, M., Hosoda, H., Date, Y., Nakazato, M., Matsuo, H., Kangawa, K., 1999. Ghrelin is a growth-hormone-releasing acylated peptide from stomach. Nature 402, 656-660.

Kolaczynski, J.W., Considine, R.V., Ohannesian, J., Marco, C., Opentanova, I., Nyce, M.R., Myint, M., Caro, J.F., 1996. Responses of leptin to short-term fasting and refeeding in humans: a link with ketogenesis but not ketone themselves. Diabetes 45, 1511-1515.

Korbonits, M., Blaine, D., Elia, M., Powell-Tuck, J., 2007. Metabolic and hormonal changes during the refeeding period of prlonged fasting. Eur. J. Endocrinol. 157, 157-166.

Le Boeuf, B.J., 1974. Male-male competition and reproductive success in elephant seals. Am. Zool. 14, 163-176

Lidgard, D.C., Boness, D.J., Bowen, W.D., McMillan, J.I., 2005. State-dependent male mating tactics in the grey seal: the importance of body size. Behav. Ecol. 16, 541-549.

Mustonen, A.-M., Saarela, S., Pyykönen, T., Nieminen, P., 2005. Endocrinologic adaptations to wintertime fasting in the male American mink, Mustela vison. Exp. Biol. Med. 230, 612-620.

Nakazato, M., Murakami, N., Date, Y., 2001. A role for ghrelin in the central regulation of feeding. Nature 409, 194-198.

Nieminen, P., Asikainen, J., Hyvärinen, H., 2001. Effects of seasonality and fasting on the plasma leptin and thyroxin levels of the raccoon dog, Nyctereutes procyonoides and the blue fox, Alopex lagopus. J. Exp. Zool. 289, 109-118.

Nieminen, P., Mustonen, A.-M., Asikainen, J., Hyvärinen, H., 2002. Seasonal weight regulation of the raccon dog, Nyctereutes procyonoides: interactions between melatonin, leptin, ghrelin and growth hormone. J. Biol. Rhythms 17, 155-163.

Nordøy, E.S., Blix, A.S., 1991. Glucose and ketone body turnover in fasting grey seal pups. Acta Physiol. Scand. 141, 563-571.

Norrelund, H., 2005. The metabolic role of growth hormone in humans with particular reference to fasting. Growth Hor. IGF Res. 15, 95-122.

Nørrelund, H., Fisker, S., Vahl, N., Børglum, J., Richelsen, B.J.S., Christiansen, J.S., Jørgensen, J.O.L., 1999. Evidence supporting a direct suppressive effect of growth hormone on serum IGFBP-1 levels. Experimental studies in normal, obese and GH-deficient adults. Growth Horm. IGF Res. 9, 52-60.

Ortiz, C.L., Costa, D., Le Boeuf, B.J., 1978. Water and energy flux in elephant seal pups fasting under natural conditions. Physiol. Zool. 51, 166-178.

Ortiz, R.M., Crocker, D.E., Houser, D.S., Webb, P.M., 2006. Angiotensin II and Aldosterone increase with fasting in breeding adult male northern elephant seals (Mirounga angustirostris). Physiol. Biochem. Zool. 79, 1106-1112.
Ortiz, R.M., Noren, D.P., Litz, B., Ortiz, C.L., 2001a. A new perspective on adiposity in a naturally obese mammal. Am. J. Physiol. 281, E1347-E1351.

Ortiz, R.M., Wade, C.E., Ortiz, C.L., 2001b. Effects of prolonged fasting on plasma cortisol and $\mathrm{TH}$ in postweaned northern elephant seal pups. Am. J. Physiol. 280, R790-R795.

Ortiz, R.M., Houser, D.S., Wade, C.E., Ortiz, C.L., 2003. Hormonal changes associated with the transition between nursing and natural fasting in northern elephant seals, Mirounga angustirostris. Gen. Comp. Endocrinol. 130, 78-83.

Sakharova, A.A., Horowitz, J.F., Surya, S., Goldenberg, N., Harber, M.P., Symons, K. Barkan, A., 2008. Role of growth hormone in regulating lipolysis, proteolysis, and hepatic glucose production during fasting. J. Clin. Endocrinol. Metab. 93, 2755-2759.

Saltiel, A.R., Kahn, C.R., 2001. Insulin signalling and the regulation of glucose and lipid metabolism. Nature 414, 799-806.

Shintani, M., Ogawa, Y., Ebihara, K., Aizawa-Abe, M., Miyanaga, F., Takaya, K., Hayashi, T., Inoue, G., Hosoda, K., Kojima, M., et al., 2001. Ghrelin, an endogenous growth hormone secretagogue, is a novel orexigenic peptide that antagonizes leptin action through the activation of hypothalamic neuropeptide $\mathrm{Y} / \mathrm{Y} 1$ receptor pathway. Diabetes 50, 227-232.

Sormo, E.G., Jussi, I., Jussi, M., Braathen, M., Skaare, J.U., Jenssen, B.M., 2005. Thyroid hormone status in gray seal, Halichoerus grypus pups from the Baltic Sea and the Atlantic Ocean in relation to organochlorine pollutants. Virus Res. 108, 83-87.

Spencer, C.A., Lum, S.M.C., Wilber, J.F., Kaptein, E.M., Nicoloff, J.T., 1983. Dynamics of serum thyrotropin and thyroid hormone changes in fasting. J. Clin. Endocrinol. Metab. 56, 883-888.

Stokkan, K.A., Vaughan, M.K., Beiter, R.J., Folkow, L.P., Martensson, P.E., Sager, G., Lydersen, C., Blix, A.S., 1995. Pineal and thyroid functions in newborn seals. Gen. Comp. Endocrinol. 98, 321-331.

Straus, D.S., Takemoto, C.D., 1990. Effect of fasting on insulin-like growth factor-I (IGF-I) and growth hormone receptor mRNA levels and IGF-I gene transcription in rat liver. Mol. Endocrinol. 4, 91-100.

Viscarra, J., Champagne, C.D., Crocker, D.E., Ortiz, R.M., 2011a. 5-AMP-activated protein kinase activity is increased in adipose tissue of northern elephant seal pups during prolonged fasting-induced insulin resistance. J. Endocrinol. 209, 317-325.

Viscarra, J., Vazquez-Medina, J.P., Crocker, D.E., Ortiz, R.M., 2011b. Glut4 is upregulated despite decreased insulin signaling during prolonged fasting in northern elephant seal pups. Am. J. Physiol. 300, R1501-R.

Vuagnat, B.A.M., Pierroz, D.D., Lalaoui, M., Englaro, P., Pralong, F.P., Blum, W.F., Aubert M.L., 1998. Evidence for a leptin-neuropeptide $Y$ axis for the regulation of growth hormone secretion in the rat. Neuroendocrinology 67, 291-300.

Weigle, D.S., Duell, P.B., Connor, W.E., Steiner, R.A., Soules, M.R., Kuijper, J.L., 1997. Effect of fasting, refeeding, and dietary fat restriction on plasma leptin levels. J. Clin. Endocrinol. Metab. 82, 561-565.

Williams, G., Cai, X.J., Elliott, J.C., Harrold, J.A., 2004. Anabolic neuropeptides. Physiol. Behav. 81, 211-222.

Woldstad, S., Jenssen, B.M., 1999. Thyroid hormones in grey seal pups, Halichoerus grypus. Comp. Biochem. Physiol. A: Comp Physiol. 122, 157-162.

Yochem, P.K., Gulland, F.M.D., Stewart, B.S., Haulena, M., Mazet, J.A.K., Boyce, W.M., 2008. Thyroid function testing in elephant seals in health and disease. Gen. Comp. Endocrinol. 155, 627-632.

Yosefi, S., Hen, G., Rosenblum, C.I., Cerasale, D.J., Beauulieu, M., Criscuolo, F., FridmanEinat, M., 2010. Lack of leptin activity in blood samples of Adelie penguin and bar-tailed godwit. J. Endocrinol. 207, 113-122.

Yu, L., Jin, W., Zhang, X., Wang, D., Zheng, J., Tang, G., Xu, S., Cho, S., Zhang, Y., 2011 Evidence for positive selection on the leptin gene in cetacea and pinnipedia. PLoS One 6 (10), e26579. 